\title{
流動床炉の下水污泥焼却性能 ${ }^{\dagger}$
}

\author{
井元義訓・笠倉忠夫*
}

日本ガイシ $(\text { 株 })^{\dagger+}$

\begin{abstract}
下水污泥流動床焼却炉の性能把握を目的として, 砂層内寸法 $700 \mathrm{~mm}$ 角の流動床炉を用 いて実験及び解析を行った。試料は実際の脱水ケーキを使用し, 空気比が $0.62 \sim 1.50$, 空 気質量速度が $0.19 \sim 0.60 \mathrm{~kg} / \mathrm{m}^{2} \cdot \mathrm{s}$ と従来の運転領域（空気比 $1.3 \sim 1.5$, 空気質量速度 0 . $\left.20 \sim 0.25 \mathrm{~kg} / \mathrm{m}^{2} \cdot \mathrm{s}\right)$ より拡大した領域で実験を行った。

実験の結果, 砂層内燃焼率はケーキ負荷及び補助燃料負荷の增加と共に低下した。また, 空気質量速度が増加すれば砂層内燃焼率は低下し, 光の燃焼は砂層内燃焼に比べフリーボ 一ド燃焼の割合が増加した。一方, 燃焼率と空気比は熱分解域では一次比例の関係にあり, 空気比が減少すれば燃焼率も低下した。 さらに, 873〜1,171 K の範囲では, 燃焼率と砂層 温度の間に明確な相関は見出せ無かった。 また, 空気質量速度の高い領域では高いヶーキ 負荷での安定燃焼の維持が可能であるが, 光の場合空気比を高める操作の必要性が認めら れた。
\end{abstract}

\section{緒言}

下水污泥焼却炉の被焼却物は, 下水污泥の濃縮・脱水 操作後の污泥（脱水ケーキ）であり，全重量中に $60 \sim 80$ $\%$ も水分を含む. その発生率は年間 $5 \sim 6 \times 10^{6}$ ton 程 度と推定される。

下水污泥焼却プロセスは, 我が国では 1960 年代半ばに 多段炉を用いて実用化されたが, 現在は流動床炉が主流 となっている。

その理由は, 脱水工程での助剂が無機系凝集剂から高 分子系凝集剂に変わった所に負う.それにより従来の多 段焼却炉の自燃時の温度制御のむずかしさや，排ガスの 脱臭の必要性がクローズアップされ, 流動床炉の優位性 が定着した。

しかし, 従来, 下水污泥流動床焼却炉についてはほと んど基礎的研究は行われず，たとえば，砂層での燃焼率 に関する研究 (Ibuki, 1983. : Ohi and Tatebayashi, 1979）や, 処理性能に関する研究（Liao, 1974）はある が, その焼却性能と空気比, ケーキ供給量, 砂層内吹込 空気量等との関係を包括した研究は無い.

従って, 今後, 下水污泥流動焼却の発展には基礎的な 性能把握が欠かせず, とくに, 燃却炬の操作因子（空気 比, ケ一キ供給量, 砂層温度等) やケーキ性状因子（水 分, 発熱量等) と, 炉の污泥処理性能の関係を把握する

† 1995 年 6 月 14 日受理

†† 7467 愛知県名古屋市瑞穂区須田町 2 番 56 号

* 豊橋技術科学大学 エコロジー工学系
必要がある.

そこで，筆者らは実際の下水処理場内に設置したパイ ロット・プラントにより, 上記課題の解明を試みた。

実験は空気比と, 砂層内に吹き込む空気量の指標であ る吹込空気質量速度を従来の下水污泥流動床燒却炉の運 転領域から拡大した領域で行い, 流動床炉の下水污泥焼 却性能の解明を試みた。本論文は実験を通して得られた データの解析により, 下水污泥焼却に用いられる流動床 炉の基礎的性能を明らかにしようとするものであり，特 に, 流動層砂層内の熱負荷状況や燃焼率と操作因子（ケ 一キ供給量, 空気比, 吹込空気質量速度) の関係を解明 した.

\section{1. 実験}

\section{1 実 験 装置}

実験装置はFig. 1に示すように，脱水ケ一キ供給系， 流動床炉本体, 排ガス処理系, 及び補機からなる。

脱水ケーキ供給系は, メインホッパー, 乾燥機, 投入 フィーダ等から構成される．試料の水分に幅を持たせる ため, 間接蒸気加熱型の乾燥機を設けた. 投入フィ一ダ は炉内空気比に影響を与えないよう，外部空気の混入を 防止できる構造のスクリュータイプとした.

また, 流動床炉は, 角型構造で, 砂層が $700 \mathrm{~mm}$ 角, フ リーボードが $900 \mathrm{~mm}$ 角, 全塔高が $8.7 \mathrm{~m}$ である. 砂層 内には，ディストリビュータと，補助燃料が必要なとき に使用するオイルガンを設け，砂層静止層高さはディス トリビュータ上端より $1 \mathrm{~m}$ とした。 

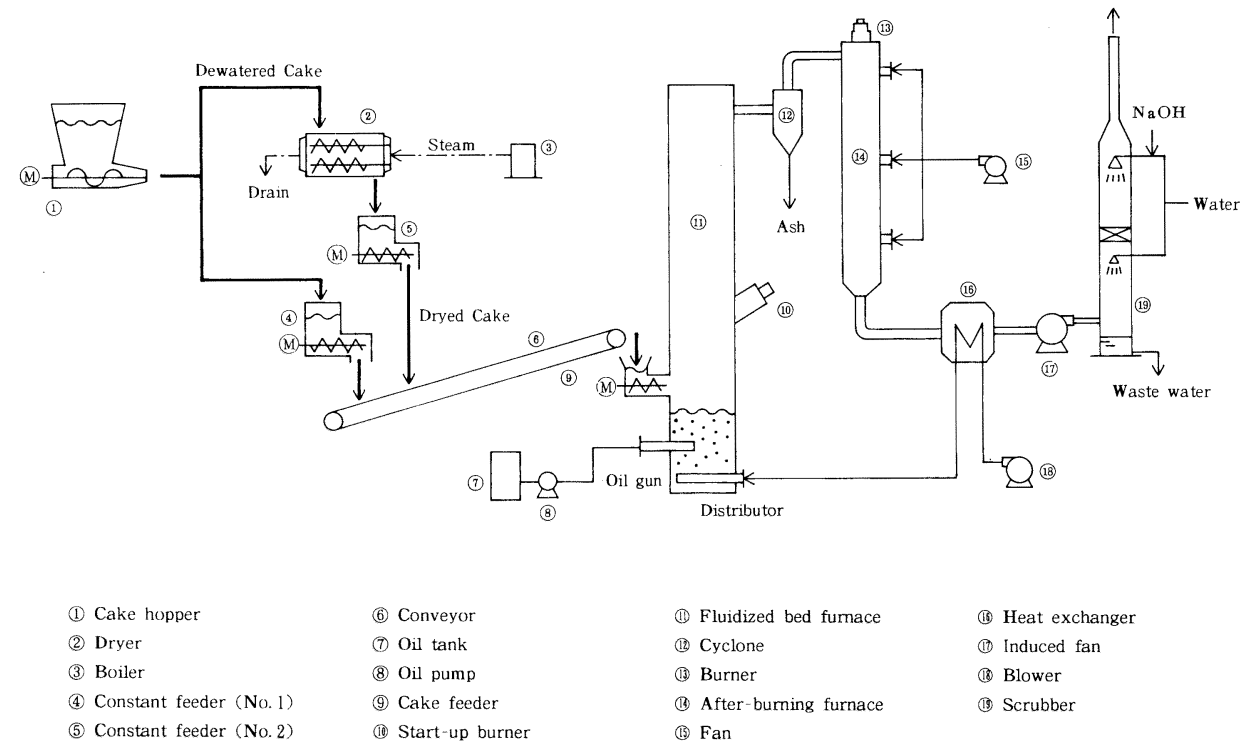

(11) Fluidized bed furnace

(16) Heat exchanger

(2) Dryer

(11) Cyclone

(11) Induced fan

(4) Constant feeder ( $\mathrm{N}(0.1)$

(9) Cake feeder

(13) Burner

(10) Blower

(5) Constant feeder (No.2)

Fig. 1 System flow-diagram of a pilot plant

Table 1 Properties of dewatered sewage sludge and fuel

\begin{tabular}{|c|c|c|c|c|c|c|}
\hline & & \multicolumn{4}{|c|}{ Sewage sludge } & \multirow{2}{*}{ Fuel } \\
\hline & & $\mathrm{A}$ & $\mathrm{B}$ & $\mathrm{C}-1$ & $C-2$ & \\
\hline \multicolumn{2}{|c|}{ Dosed agent } & High polymer & High polymer & High polymer & Iron chloride & - \\
\hline Heating Value & $(\mathrm{MJ} / \mathrm{kgDS})$ & $16.4 \sim 17.1$ & $165 \sim 18.9$ & $17.6 \sim 19.5$ & $12.3 \sim 12.6$ & 45.2 \\
\hline Moisture & $(\%)$ & $59.1 \sim 78.5$ & $43.8 \sim 81.4$ & $65.0 \sim 80.0$ & $64.6 \sim 83.0$ & - \\
\hline Volatile matter & $($ dry wt $\%)$ & $72.6 \sim 75.6$ & $75.9 \sim 82.1$ & $77.1 \sim 83.5$ & $55.5 \sim 57.8$ & - \\
\hline Fixed Carbon & (dry wt\%) & $10.8 \sim 11.6$ & $9.2 \sim 9.8$ & $10.3 \sim 10.8$ & $4.5 \sim 4.7$ & - \\
\hline Carbon & (dry wt\%) & $37.7 \sim 39.6$ & $37.5 \sim 42.9$ & $41.0 \sim 44.9$ & $29.8 \sim 30.0$ & 85.4 \\
\hline Hydrogen & (dry wt\%) & $5.2 \sim 5.5$ & $6.0 \sim 6.4$ & $5.7 \sim 6.6$ & $4.2 \sim 4.3$ & 12.6 \\
\hline Nitrogen & (dry wt\%) & $3.5 \sim 5.0$ & $4.4 \sim 5.0$ & $4.5 \sim 4.8$ & $4.0 \sim 4.6$ & 0.8 \\
\hline
\end{tabular}

DS : dried sludge

排ガス処理系は残渣（灰）捕集用のサイクロン，未燃 熱分解ガス燃焼用の再燃焼炉，流動空気の昇温を行う熱 交換器, 燃焼がスの脱硫等を行うガス洗煙塔および誘引 ファンより構成される.

\section{2 実験 試 料}

実験試料には実際の下水処理場より発生した高分子凝 集剂注入脱水ケーキを 3 種類, 塩化第二鉄 - 石灰注入脱 水ケーキを 1 種類用いた. 一部のケーキは水分值の幅を 拡げるため, 乾燥機によってある程度水分を除去したも のを用いた。実験に用いたケーキと補助燃料（A 重油） の性状を Table 1 に示した.

なお，流動媒体は相馬 4 号硅砂を使用し，その性状は

Table 2 に示した.
Table 2 Properties of solid particle

\begin{tabular}{c|c||c|c}
\hline Size of diameter $(\mu \mathrm{m})$ & Ratio $(\%)$ & Material & Ratio(\%) \\
\hline$>1190$ & 0.1 & $\mathrm{SiO}_{2}$ & 95.7 \\
\hline $840-1190$ & 5.3 & $\mathrm{Al}_{2} \mathrm{O}_{3}$ & 2.33 \\
\hline $590-840$ & 68.5 & $\mathrm{Fe}_{2} \mathrm{O}_{3}$ & 0.12 \\
\hline $420-590$ & 25.9 & Another & 1.85 \\
\hline$<420$ & 0.2 & & \\
\hline
\end{tabular}

\section{3 実 験 方 法}

実験は炉性能に影響を与える操作因子（ケーキ供給量, 空気比，吹込空気質量速度）とケーキ性状因子（固形分 比 $(S)$, 発熱量) を変化させて行った. 従来, 実運転で はフリーボード空塔速度が $0.8 \sim 1.0 \mathrm{~m} / \mathrm{s}$ (吹込空気質量 
Table 3 Fluid characteristics of fluidized bed furnace for sewage sludge at 1073K

\begin{tabular}{|c|c|c|}
\hline Items & Equations for calculation & Calculated results \\
\hline \multicolumn{3}{|l|}{ Gas velocities } \\
\hline $\mathrm{u}_{\mathrm{mf}}:$ minimum fluidization velocity & $\mathrm{u}_{\mathrm{mf}}=\mathrm{d}_{\mathrm{p}}^{2}\left(\rho_{\mathrm{p}}-\rho_{\mathrm{a}}\right) \cdot \mathrm{g} / 1650 \mu\left(\operatorname{Ar}<1.9 \times 10^{4}\right)$ & 0.125 \\
\hline $\mathrm{u}_{\mathrm{mb}}:$ minimum bubbling velocity & $\begin{aligned} \mathrm{u}_{\mathrm{mb}}= & 2.07 \exp \left(0.716 \mathrm{X}_{\mathrm{F}}\right) d_{\mathrm{p}} \cdot \rho_{\mathrm{a}}{ }^{0.06} / \mu^{0.347} \\
& \left(\text { if } \mathrm{u}_{\mathrm{mb}}<\mathrm{u}_{\mathrm{mf}}, \text { then } \mathrm{u}_{\mathrm{mb}} \rightarrow \mathrm{u}_{\mathrm{mf}}\right)\end{aligned}$ & 0.125 \\
\hline $\mathrm{u}_{\mathrm{s}}$ : slugging velocity & $\left(\mathrm{u}_{\mathrm{s}}-\mathrm{u}_{\mathrm{mt}}\right) / 0.35 \cdot \mathrm{gD}_{\mathrm{t}}=0.2$ & (at $\stackrel{0.308}{\mathrm{D}_{\mathrm{t}}=0.7 \mathrm{~m}}$ ) \\
\hline $\mathrm{u}_{\mathrm{t}}:$ terminal velocity & $\begin{aligned} \mathrm{u}_{\mathrm{t}}= & \mathrm{d}_{\mathrm{p}}\left\{4 \mathrm{~g}^{2} \cdot\left(\rho_{\mathrm{p}}-\rho_{\mathrm{a}}\right)^{2} / 225 \cdot \rho_{\mathrm{a}} \cdot \mu\right\}^{1 / 3} \\
& \left(5.76<\operatorname{Re}_{\mathrm{t}} \leqq 517 \text { or } 104<\operatorname{Ar} \leqq 9.43 \times 10^{4}\right)\end{aligned}$ & 5.55 \\
\hline \multicolumn{3}{|l|}{ dimensionless numbers } \\
\hline $\operatorname{Re}_{\mathrm{r}}:$ Reynolds number $\left(\right.$ at $\left.\mathrm{u}=\mathrm{u}_{0}\right)$ & $\operatorname{Re}_{\mathrm{r}}=d_{\mathrm{p}} \cdot \rho_{\mathrm{a}} \cdot \mathrm{u}_{0} / \mu=\mathrm{d}_{\mathrm{p}} \cdot \mathrm{G}_{\mathrm{a}} / \mu$ & $2.70 \sim 8.11$ \\
\hline $\operatorname{Re}_{t}:$ Reynolds number $\left(\right.$ at $\left.u=u_{t}\right)$ & $\operatorname{Re}_{\mathrm{t}}=d_{\mathrm{p}} \cdot \rho_{\mathrm{a}} \cdot \mathrm{u}_{\mathrm{t}} / \mu$ & 24.67 \\
\hline Ar: Archimedes number & $\operatorname{Ar}=d_{\mathrm{p}}^{3} \cdot \rho_{\mathrm{a}}\left(\rho_{\mathrm{p}}-\rho_{\mathrm{a}}\right) \cdot \mathrm{g} / \mu^{2}$ & 918 \\
\hline
\end{tabular}

* $\mathrm{X}_{\mathrm{F}}$ : percentage of fine particles $(\mathrm{d}<0.045 \mathrm{~mm}), \quad d_{\mathrm{p}}=6.0 \times 10^{-4} \mathrm{~m}, \rho_{\mathrm{a}} \cdot \mathrm{u}_{0}=0.2 \sim 0.6 \mathrm{~kg} / \mathrm{m}^{2} \cdot \mathrm{s}$

$\mathrm{D}_{\mathrm{t}}$ : diameter of nand bed, $\rho_{\mathrm{p}}=2.6 \times 10^{-3} \mathrm{~kg} / \mathrm{m}^{3}, \quad \rho_{\mathrm{a}}=0.329 \mathrm{~kg} / \mathrm{m}^{3}, \quad \mu=44.4 \times 10^{-6} \mathrm{~kg} / \mathrm{m} \cdot \mathrm{s}$

速度 $\rho_{\mathrm{a}} \cdot u_{0}\left(\mathrm{~kg} / \mathrm{m}^{2} \cdot \mathrm{s}\right)$ に換算して $0.2 \sim 0.3 \mathrm{~kg} / \mathrm{m}^{2} \cdot \mathrm{s}$ 程度となるような操作が行われている。そこで，本実験 では従来運転域を拡大した領域 $\left(\rho_{\mathrm{a}} \cdot u_{0} 0.2 \sim 0.6 \mathrm{~kg} /\right.$ $\left.\mathrm{m}^{2} \cdot \mathrm{s}\right)$ で実験を行い，砂層内流速の高い領域，即ち，吹 込空気質量速度の高い領域での処理能力や燃焼状況を把 握した。

流動状況を表わす特性值を既往の研究式 (Muchi et al., 1984）により算出し Table 3 にまとめた。これから もわかるが本実験の流動状況は気泡流動領域に分類され, これは実験での視覚観察状況とも一致した.

なお, 空気比 $m$ は流動層に投入したケーキと補助燃料 の可熱分に対する空気比として次式で定義した。

$$
m=F_{\mathrm{ai}} /\left(F_{\mathrm{c}} \cdot S \cdot k_{\mathrm{c}}+F_{\mathrm{f}} \cdot k_{\mathrm{f}}\right)
$$

ここで， $F_{\mathrm{c}}, F_{\mathrm{f}}, F_{\mathrm{al}}$ は流動層砂層への投入ケーキ, 補 助燃料, 投入 (流動) 空気の単位時間当たりの供給量で あり，また， $k_{c} ， k_{\mathrm{f}}$ は投入ケーキ固形分及び補助燃料の理 論燃焼空気量である。

また, 空気比 $m$ については, $m=0.62 \sim 1.50$ とし, 熱 分解条件下 $(m<1.0)$ での実験も行った．熱分解操作 は，下水污泥脱水ケーキ中のクロムの酸化・溶出の抑制 効果が高いが, クロムの挙動については他に報告 (Kasakura and Imoto, 1991）したので本論文では，熱分解時 のケーキ処理性能の報告にとどめる.

実験では，まず吹込空気質量速度 $\rho_{\mathrm{a}} \cdot u_{0}$ を固定し，投 入ケーキ量を変化させた. 従って, 投入ケーキ量の変化 に伴い, 空気比 $m$ も変化した。このとき，フリーボード 温度 $\left(T_{\mathrm{f}}\right)$ 及び砂層温度 $\left(T_{\mathrm{s}}\right)$ については以下の条件を 満足するものを採取デー夕とした，但し，デー夕の採取 は運転状態が 2 時間以上定常状態に達してから行った。

$$
\begin{aligned}
& 1,023 \mathrm{~K} \leqq T_{\mathrm{f}} \leqq 1,173 \mathrm{~K} \\
& 823 \mathrm{~K} \leqq T_{\mathrm{s}} \leqq 1,173 \mathrm{~K}
\end{aligned}
$$

フリーボード及び砂層の温度上限を $1,173 \mathrm{~K}$ とした のは，炉内でのクリンカ防止のためである．流動層温度 は補助燃料を使用する場合 $973 \sim 1,073 \mathrm{~K}$ を目標として, 補助燃料の量を調整し温度範囲を制御した。一方，自燃 条件では燃焼が継続し，砂層及びフリーボードの温度が 式 (2), 式 (3) の範囲に入る限りは, 操作条件は変更し なかった．主な運転状況は下記の通りである。

砂層空塔速度 : $u_{0}=0.433 \sim 1.70 \mathrm{~m} / \mathrm{s}$

空気質量速度 $: \rho_{\mathrm{a}} \cdot u_{0}=0.19 \sim 0.60 \mathrm{~kg} / \mathrm{m}^{2} \cdot \mathrm{s}$

空 気 比: $m=0.62 \sim 1.50$

砂 層温度: $T_{\mathrm{s}}=823 \sim 1,171 \mathrm{~K}$

ケーキ投入量： $F_{\mathrm{c}}=194 \sim 633 \mathrm{~kg} / \mathrm{h}$

\section{2. 実験結果と光の考察}

\section{1 砂層内燃焼率}

流動床炉の熱負荷状況や砂層内燃焼率は流動床炉の熱 的状況の重要な指標である。これらの考察を通して，流 動床炉の下水污泥焼却性能が明らかにできるであろう。 砂層内燃焼率には種々の因子が影響を及ぼす。 系外から流動層への供給物は投入ケーキ, 補助燃料, 投入（流動）空気の三種であり，それぞれの単位時間当 たりの供給量を $F_{\mathrm{c}}, F_{\mathrm{f}}, F_{\mathrm{a}}$ とすると炉の污泥処理性能の 指標であるケーキ負荷 $r_{\mathrm{c}}$ は，砂層断面積を $A_{\mathrm{b}}$ とすると $F_{\mathrm{c}} / A_{\mathrm{b}}\left(\mathrm{kg} / \mathrm{m}^{2} \cdot \mathrm{h}\right)$ で表わされ, 補助燃料負荷 $r_{\mathrm{f}}$ は $F_{\mathrm{f}} /$ $A_{\mathrm{b}}\left(\mathrm{kg} / \mathrm{m}^{2} \cdot \mathrm{h}\right)$ で表される。 まず，ケーキ負荷 $r_{\mathrm{c}}$ と補助 燃料負荷 $r_{\mathrm{f}}$ が砂層内燃焼率に与之る影響を調べる.

砂層内燃焼率 $\eta_{\mathrm{s}}$ は砂層部の熱収支から得られる次式 によって求めた。

また，その算出にあたっては，ケーキの可燃分の補助 燃料は砂層で燃焼率 $\eta_{\mathrm{s}}$ の割合で完全燃焼し, 残りの(1$\eta_{\mathrm{s}}$ ）は未燃ガスとしてフリーボードへ移るものとした. 


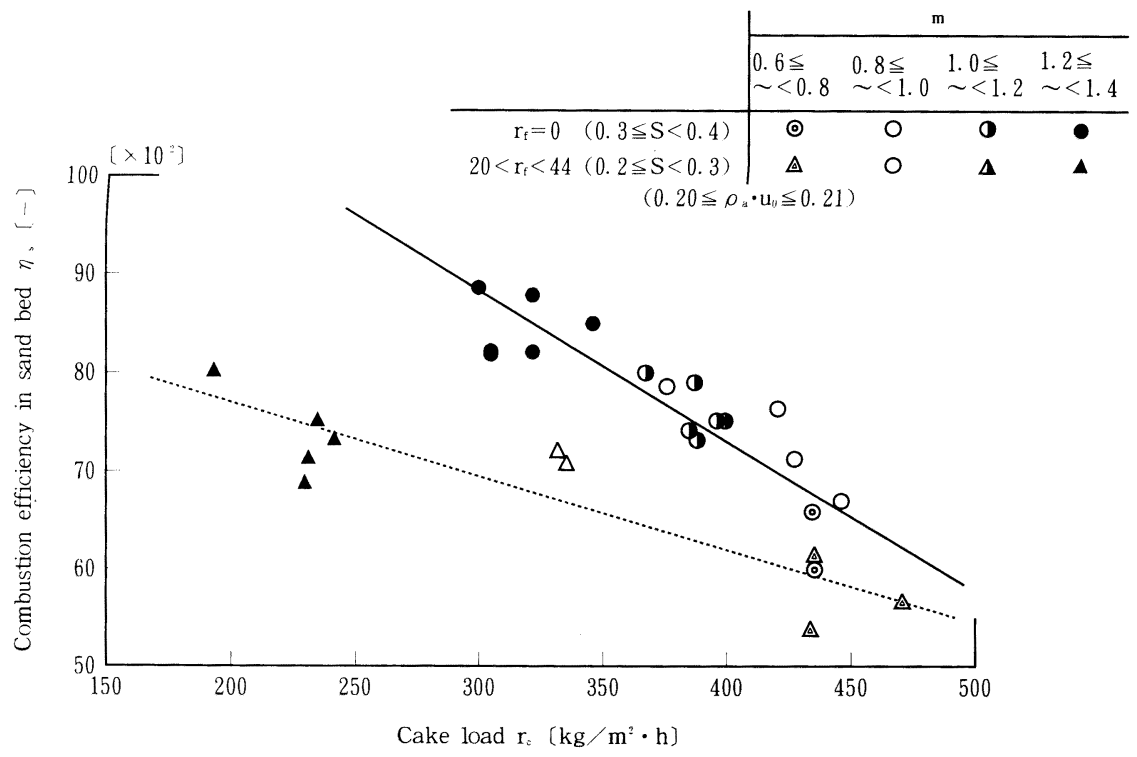

Fig. 2 Relation between cake load $\left(r_{\mathrm{c}}\right)$ and combustion efficiency $\left(\eta_{\mathrm{s}}\right)$

$$
\begin{aligned}
& Q_{\mathrm{IN}}=Q_{\mathrm{OUT}} \\
& Q_{\mathrm{IN}}=\eta_{\mathrm{s}} \cdot\left(Q_{\mathrm{c}}+Q_{\mathrm{f}}\right)+Q_{\mathrm{al}}(\mathrm{W}) \\
& Q_{\mathrm{OUT}}=Q_{\mathrm{g}}+Q_{\mathrm{H}_{2} \mathrm{O}}+Q_{\text {comb }}+Q_{\mathrm{ash}}+Q_{\mathrm{LOS}}[\mathrm{W}]
\end{aligned}
$$

ここで， $Q_{\mathrm{c}}, Q_{\mathrm{f}}$ は砂層に供給したケーキおよび補助燃 料の総発熱量であり， $Q_{\mathrm{a} 1}$ は流動空気の持込顕熱である. また, $Q_{9}$ は砂層上の燃焼排がス顕熱, $Q_{\mathrm{H}_{2} \mathrm{O}}$ は水分蒸発潜 熱, $Q_{\text {comb }}$ は砂層上の排出未燃ガス顕熱， $Q_{\text {ash }}$ 灰顕熱, $Q_{\text {Los }}$ は壁損失熱であり, これらは以下の式により求め た.

$$
Q_{\mathrm{g}}=\frac{1}{3,600}\left(C_{\mathrm{pdry}} \cdot F_{\mathrm{gdry}}+C_{\mathrm{pH}_{2} \mathrm{O}} \cdot F_{\mathrm{gH}_{2} \mathrm{O}}\right)\left(T_{\text {out }}-293\right)
$$

$$
\begin{aligned}
\text { ここで } & \\
F_{\mathrm{gdry}}= & F_{\mathrm{c}} \cdot S \cdot V \cdot \eta_{\mathrm{s}} \cdot\left(1-9 h_{\mathrm{c}}\right)+F_{\mathrm{f}} \cdot \eta_{\mathrm{s}} \cdot\left(1-9 h_{\mathrm{f}}\right) \\
& +F_{\text {aldry }} \\
F_{\mathrm{gH}_{2} \mathrm{O}}= & F_{\mathrm{c}} \cdot(1-S)+F_{\mathrm{c}} \cdot S \cdot V \cdot \eta_{\mathrm{s}} \cdot 9 h_{\mathrm{c}}+F_{\mathrm{f}} \cdot \eta_{\mathrm{s}} \cdot 9 h_{\mathrm{f}} \\
& +F_{\mathrm{aiH} 2 \mathrm{O}} \\
Q_{\mathrm{H}_{2} \mathrm{O}}= & \frac{1}{3,600}\left\{F_{\mathrm{c}} \cdot(1-S)+F_{\mathrm{c}} \cdot \eta_{\mathrm{s}} \cdot S \cdot V \cdot 9 h_{\mathrm{c}}\right. \\
& \left.+F_{\mathrm{f}} \cdot \eta_{\mathrm{s}} \cdot 9 h_{\mathrm{f}}\right\} \cdot L \\
Q_{\mathrm{comb}}= & \frac{1}{3,600} \cdot C_{\mathrm{pcomb}} \cdot\left(1-\eta_{\mathrm{s}}\right) \cdot\left(F_{\mathrm{c}} \cdot S \cdot V+F_{\mathrm{f}}\right) \\
& \cdot\left(T_{\mathrm{out}}-293\right) \\
Q_{\mathrm{ash}}= & \frac{1}{3,600} \cdot C_{\mathrm{pash}} \cdot F_{\mathrm{c}} \cdot(1-S) \cdot V \\
Q_{\mathrm{Los}}= & \frac{1}{3,600} \cdot A_{\mathrm{s}} \cdot h_{\mathrm{s}} \cdot\left(T_{\mathrm{s}}-293\right)
\end{aligned}
$$

まず，ケーキ負荷 $r_{\mathrm{c}}$ と砂層内燃焼率 $\eta_{\mathrm{s}}$ の関係を Fig. 2 に示す。ここでは $\rho_{\mathrm{a}} \cdot u_{0}$ 及び $r_{\mathrm{f}}$ は一定条件とした．補 助燃料の有無に拘わらずケーキ負荷の増加とともに燃焼 率は低下する。

しかし, 空気質量速度 $\rho_{\mathrm{a}} \cdot u_{0}$ や空気比 $m$ はケーキ負荷 $r_{\mathrm{c}}$ と相互に影響し，たとえば Fig. 2 からもわかるように 空気質量速度を一定とすると, ケーキ負荷 $r_{\mathrm{c}}$ 或いは補助 燃料負荷 $r_{\mathrm{f}}$ の高い領域は低い領域と比較して低空気比 操作となる.従って Fig. 2 ではケーキ負荷 $r_{\mathrm{c}}$ の増加によ $\eta$ 燃焼率 $n_{\mathrm{s}}$ と同時に空気比 $m$ も低減している.

一方, 補助燃料負荷 $r_{\mathrm{f}}$ の影響は Fig. 3 に示す. 補助燃 料負荷の増加とともに燃焼率は低下する.

空気比が燃焼率に及ぼす影響については，Fig. 2 と同 様の傾向が見られる。

しかし, Fig. 2 やFig. 3 からは空気比 $m$ とケーキ負荷 $r_{\mathrm{c}}$ (或いは補助燃料負荷 $r_{\mathrm{f}}$ )のどちらが強く砂層燃焼率に 影響を及ぼすか判然としない.

従って，次にケーキ負荷と補助燃料負荷の両方を含む 指標として炉床熱負荷を用い, 両者の関係を調べる.

Fig. 4 に流動層砂層内の顕熱を含む炉床熱負荷 $q_{t}$ と 燃焼率 $\eta_{\mathrm{s}}$ の関係を空気比 $m$ を変数として示す.ここで, 流動層砂層の顕熱を含む炉床熱負荷 $q_{t}$ と有効炉床熱負 荷 $q_{\mathrm{e}}$ は次式で定義する.

$$
\begin{aligned}
& q_{\mathrm{t}}=\left(Q_{\mathrm{c}}+Q_{\mathrm{f}}+Q_{\mathrm{a} 1}\right) / A_{\mathrm{b}}\left[\mathrm{W} / \mathrm{m}^{2}\right) \\
& q_{\mathrm{e}}=\left[\eta_{\mathrm{c}}\left(Q_{\mathrm{c}}+Q_{\mathrm{f}}\right)+Q_{\mathrm{ai}}\right] / A_{\mathrm{b}}\left[\mathrm{W} / \mathrm{m}^{2}\right]
\end{aligned}
$$

Fig. 2 やFig. 3 の結果からも類推できるが, Fig. 4 か ら同一空気比であっても炉床熱負荷が増加すると砂層内 


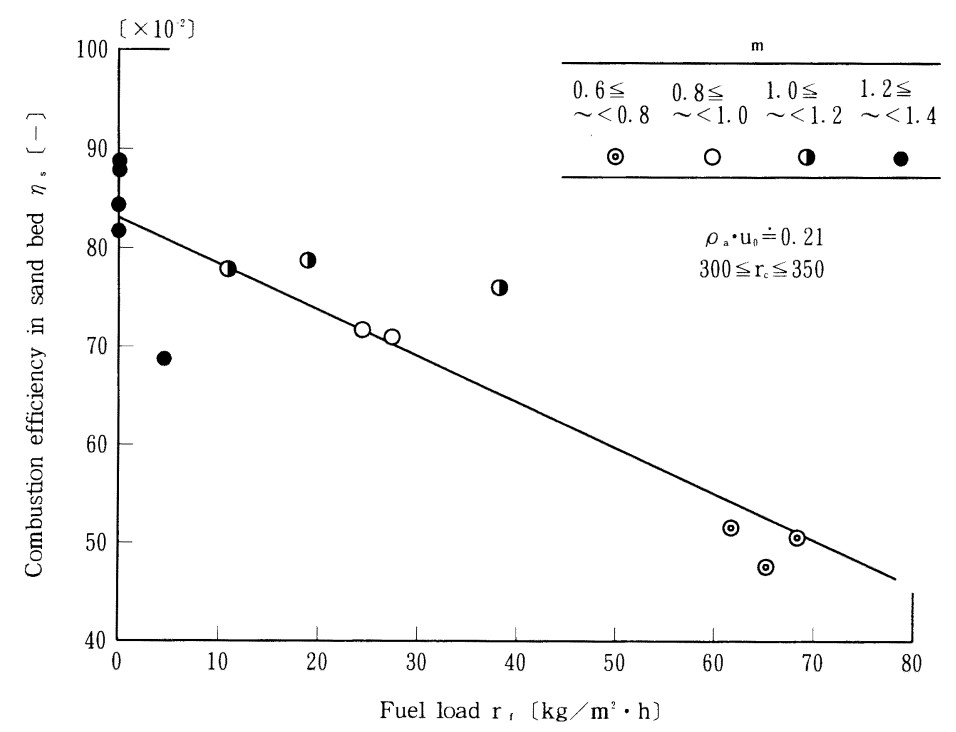

Fig. 3 Relation between fuel load $\left(r_{\mathrm{f}}\right)$ and combustion efficiency $\left(\eta_{\mathrm{s}}\right)$

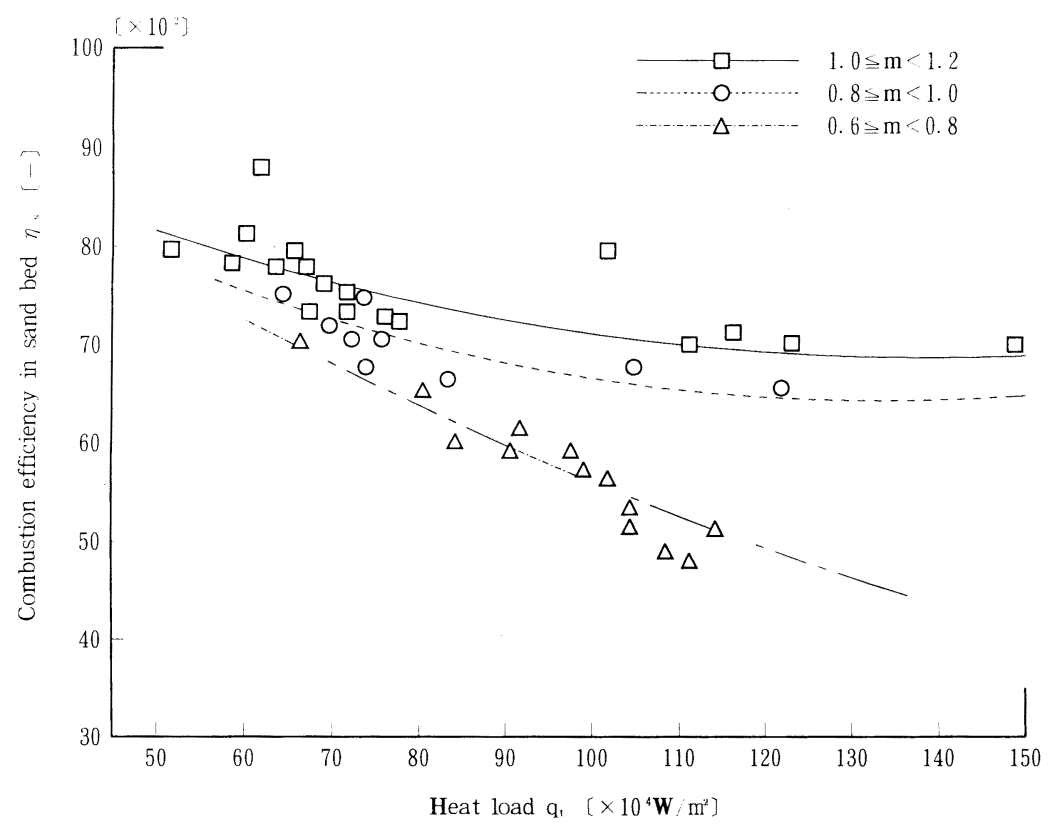

Fig. 4 Relation between heat load $\left(q_{\mathrm{t}}\right)$ and combustion efficiency $\left(\eta_{\mathrm{s}}\right)$

燃焼率の低下を招くことがわかる.

また, 炉床熱負荷 $q_{t}$ が同一でも空気比 $m$ が低いと,や はり炭層内燃焼率 $\eta_{\mathrm{s}}$ が低いことがわかる.すなわち, 砂 層内燃焼率 $\eta_{\mathrm{s}}$ は炉床熱負荷 $q_{t}$ が高いほど, 或いは, 空気 比 $m$ が低いほど低下する.そして特に低空気比の領域で は炉床熱負荷と砂層燃焼率は負の一次相関にあることが わかる。

次に空気比と砂層内燃焼率の関係を Fig. 5 に示す. 両 者の関係は空気比 $m<1.0$ の領域で求めた実験式
(Ibuki, 1983)

$$
\eta_{\mathrm{s}}=0.65 m+0.105
$$

と傾向が一致する. 但し, 式 (16) は弪料ケーキの水分 が，ほぼ絶乾状態（S>0.9）での回帰式であるが，本実 験試料の様に水分を多く含む通常の脱水ケーキでも熱分 解域では燃焼率と空気比はほぼ一次比例することがわか る.

次に空気質量速度 $\rho_{\mathrm{a}} \cdot u_{0}$ と燃焼率 $\eta_{\mathrm{s}}$ の関係を Fig. 6 に示す. 空気質量速度 $\rho_{\mathrm{a}} \cdot \mathcal{u}_{0}$ が増加すると砂層内燃焼率 


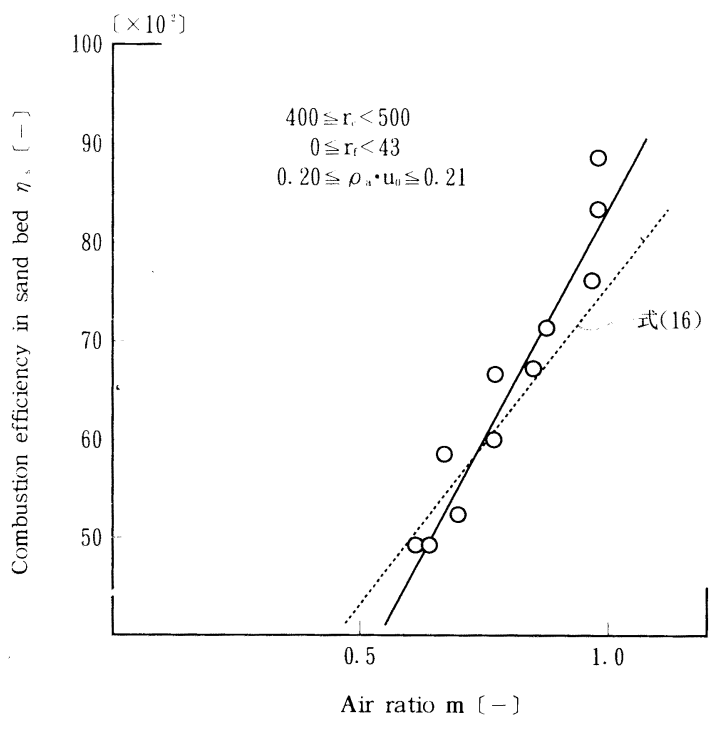

Fig. 5 Relation between air ratio $(m)$ and combustion efficiency $\left(\eta_{\mathrm{s}}\right)$

が低下する. 但し，この傾向はFig. 2 の結果から類推で きる、すなわち，空気比 $m$ を表わす式(1)を変形した下 式から, 空気比 $(m)$ 及びケーキ固形分比 $(S)$ が一定で あれば, ケーキ負荷 $r_{\mathrm{c}}$ と空気質量速度 $\rho_{\mathrm{a}} \cdot u_{0}$ は一次比例 の関係にあるからである。

$$
\begin{aligned}
& m=\frac{\rho_{\mathrm{a}} \cdot u_{0}}{r_{\mathrm{c}}} \cdot g(S, f) \\
& g(S, f)=\frac{3,600}{S} \cdot \frac{1}{k_{\mathrm{c}}\left(1+\frac{k_{\mathrm{f}}}{k_{\mathrm{c}}} \cdot \frac{H_{\mathrm{ch}}}{H_{\mathrm{fh}}} \cdot \frac{f}{1-f}\right)} \\
& f=Q_{\mathrm{f}} /\left(Q_{\mathrm{c}}+Q_{\mathrm{f}}\right)
\end{aligned}
$$

ここで， $H_{\mathrm{ch}} ， H_{\mathrm{fh}}$ はケーキ固形分および補助燃料の高 位発熱量 $[\mathrm{MJ} / \mathrm{kg}]$ である。

なお，砂層温度は下水污泥流動床焼却炉の重要な操作 因子であるが，自燃条件 $\left(r_{\mathrm{f}}=0\right)$ での砂層温度と燃焼率 の関係を Fig. 7 に示す。なお，図中の白丸等の記号の添 数字は空気比 $m$ とケーキ負荷 $r_{\mathrm{c}}$ を示す.

砂層温度と燃焼率の関係については, 大井ら (Ohi and Tatebayashi, 1979) が補助燃料負荷の高い条件で，広い 温度領域で砂層温度が高くなると砂層燃焼率も高くなる 実験結果を示している。一方，Fig. 7 の実験は自燃条件 $\left(r_{\mathrm{f}}=0\right)$ であり, また本実験の温度範囲が限られているこ ともあり, 燃焼率 $\eta_{\mathrm{s}}$ と砂層温度との間には明確な相関は 見出せなかった。

また，自燃条件では温度制御をしなかったが，砂層温 度はケーキ性状 $S$ 及び空気比 $m$ の影響を受け変化する ことが Fig. 7 からわかる.

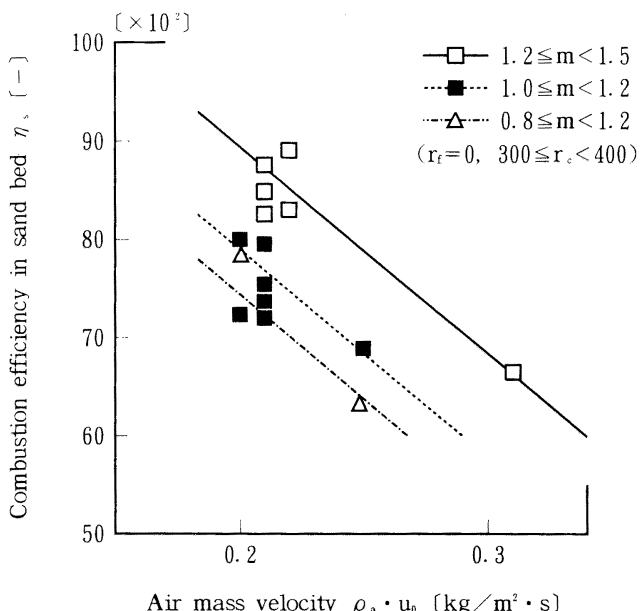

Fig. 6 Relation between air mass velocity $\left(\rho_{\mathrm{a}} \cdot u_{0}\right)$ and combustion efficiency $\left(\eta_{\mathrm{s}}\right)$

\section{2 下水污泥処理能力（ケーキ負荷）}

炉の污泥処理能力の指標である, ケーキ負荷 $r_{\mathrm{c}}$, 水分 負荷 $r_{\mathrm{w}}$, 固形分負荷 $r_{\mathrm{s}}$ の 3 種の指標の間には $r_{\mathrm{c}}=r_{\mathrm{w}}+$ $r_{\mathrm{s}}$ の関係が成立する. その中で最も簡便な指標はケ一キ 負荷 $r_{\mathrm{c}}$ である.

実際の下水污泥流動床炉の設計ではケ一キ負荷の設定 値により塔径が決定される．塔径を小さくすることで， 設備費用を下げることが可能であるが，そのためには， ケーキ負荷の設定を高くする必要がある。しかし，高い ケーキ負荷の設定は，実際の操炉で，不安定な燃焼を招 くことがある.従って適正なケーキ負荷の把握が実用上 は重要となる.

ケーキ負荷については, 従来, 下式 (Liao, 1974) が知 られている。

$$
r_{\mathrm{c}}=\frac{1}{S} \cdot \exp (5.10 \cdot S+2.70)\left[\mathrm{kg} / \mathrm{m}^{2} \cdot \mathrm{h}\right]
$$

しかし,この式は広いケーキ固形分比 $(S)$ の領域に適 用できない（Kasakura and Imoto, 1991)。また，本実 験範囲の高い空気質量速度 $\left(\rho_{\mathrm{a}} \cdot u_{0}>0.3\right)$ や熱分解条件 $(m<1.0)$ が考慮されていない.

前項で種々の操作因子が砂層燃焼率に与える影響を調 べた. 例えば, Fig. 2 では, ケーキ負荷の増加に伴い砂層 内燃焼率は低下し，Fig. 6 では空気質量速度の増加に伴 い砂層内燃焼率は低下した。一方，ケーキ負荷は自由に 設定できる量であるが, 式 (2), 式（3）の温度条件があ るため, 前述のように他の操作因子である空気質量速度 や空気比の影響を受け，それらは相互に関係し合う。次 に，これらの関係が下水污泥処理能力にどう影響を及ぼ すか調べてみる。

自燃 $\left(r_{\mathrm{f}}=0\right)$ 条件でかつ式 (2) と式 (3) の温度条件 


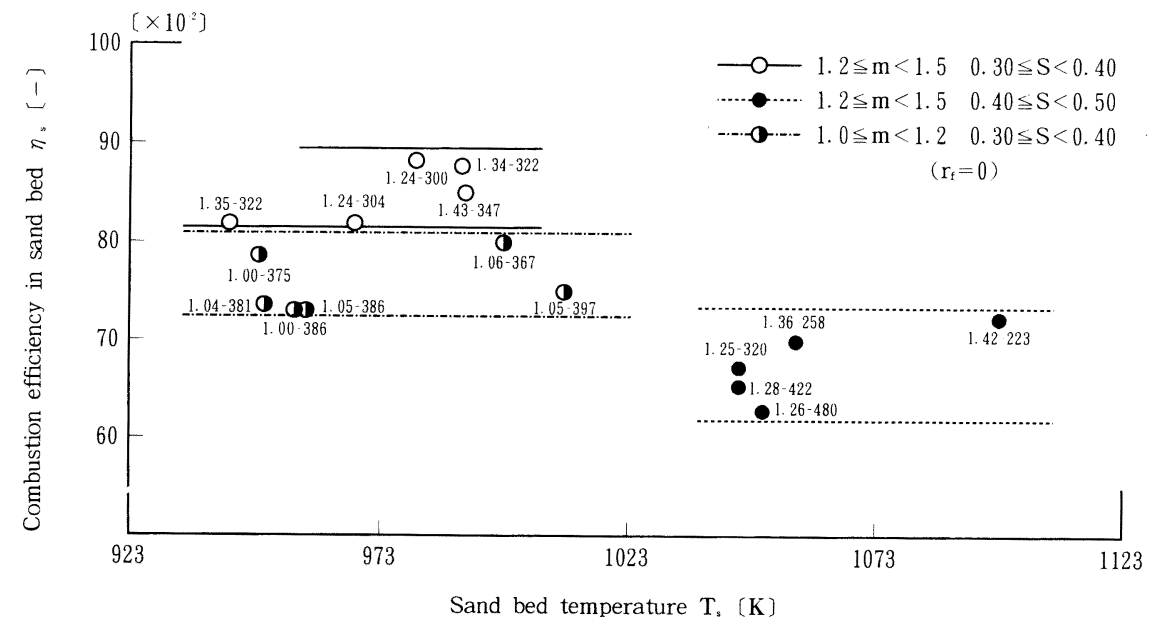

Fig. 7 Relation between sand bed temperature $\left(T_{\mathrm{s}}\right)$ and combustion efficiency $\left(\eta_{\mathrm{s}}\right)$

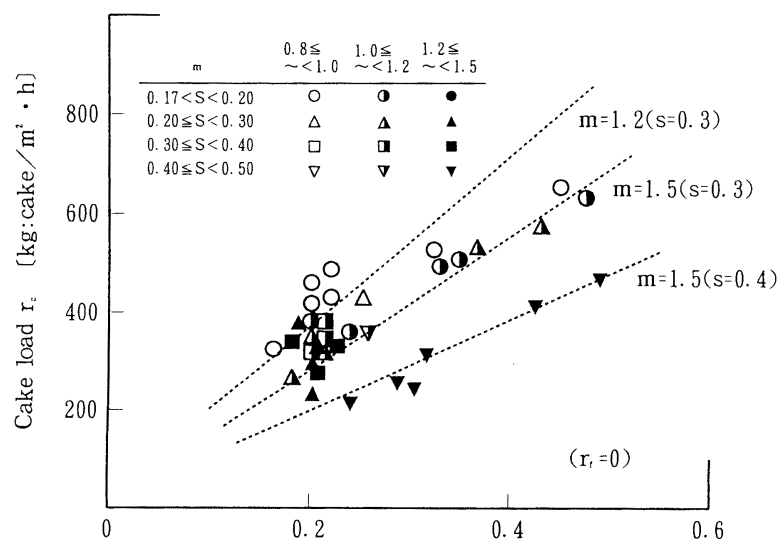

Air mass velocity $\rho \cdot \cdot \mathrm{u}_{0}\left[\mathrm{~kg} / \mathrm{m}^{2} \cdot \mathrm{s}\right]$

Fig. 8 Relation between air mass velocity $\left(\rho_{\mathrm{a}} \cdot u_{0}\right)$ and cake load $\left(r_{\mathrm{c}}\right)$

を満たす空気質量速度 $\rho_{\mathrm{a}} \cdot u_{0}$ とケーキ負荷 $r_{\mathrm{c}}$ の関係を, 空気比 $m$ 及びケーキ固形分比 $S$ を変数として Fig. 8 に 示す. Fig. 8 から, 本実験範囲では空気質量速度が増加す るとケーキ負荷もほぼ直線的に増加することがわかる。

これは, ケーキ負荷を増大する，すなわち炉のケーキ 処理能力をアップするには空気質量速度を大きくとるこ とが有効なことを示している，ちなみに，式（17）から 導かれる, 空気比が 1.2 と 1.5 の場合の空気質量速度 $\rho_{\mathrm{a}} \cdot u_{0}$ とケーキ負荷 $r_{\mathrm{c}}$ の関係 $(f=0, S=0.3,0.4$ と仮 定）を破線でFig. 8 に示す．実験の傾向が概ね式（17） から求めた直線と合致することがわかる。これは, 空気 質量速度の高い領域でもクリンカ防止等の温度条件（式 （2），式（3））を満足しつつ高いケーキ負荷での安定燃焼 の維持が可能であることを示している. しかし，高いケ 一キ負荷では, フリーボードの燃焼割合が増加し，フリ 一ボードの温度上昇によるクリンカ発生が生じるため,

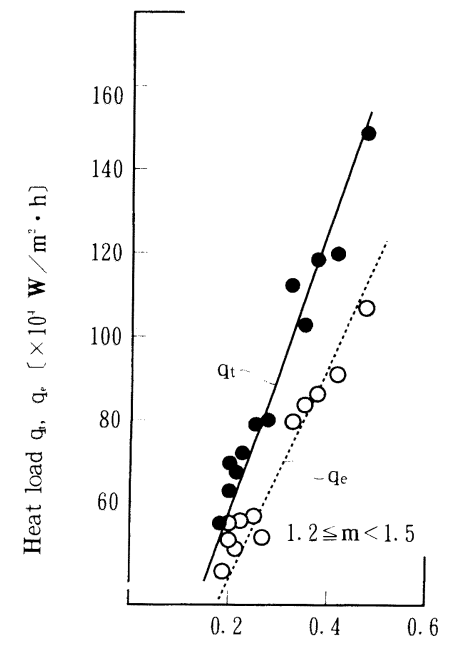

Air mass velocity $\rho_{a} \cdot \mathrm{u}_{\mathrm{n}}\left[\mathrm{kg} / \mathrm{m}^{2} \cdot \mathrm{s}\right]$

Fig. 9 Relation between air mass velocity $\left(\rho_{\mathrm{a}} \cdot u_{0}\right)$ and heat load $\left(q_{\mathrm{t}}, q_{\mathrm{e}}\right)$

安定燃焼の維持には空気比を上げざるを得ない。

Fig. 8 からも高空気質量速度では実際の操作は式 (17) から導かれるケーキ負荷より低いケーキ負荷となること がわかる，言い換えると，高い空気比での操作とせざる を得ない傾向が示される.

高いケーキ負荷でのフリーボード燃焼の割合増加は, 空気質量速度 $\rho_{\mathrm{a}} \cdot u_{0}$ と炉床熱負荷 $q_{\mathrm{t}}$ 及び有効炉床熱負 荷 $q_{\mathrm{e}}$ の関係を示す Fig.9からもわかる. Fig. 9 から, 空 気質量速度を增加すれば炉床熱負荷 $q_{\mathrm{t}}$ と有効炉床熱負 荷 $q_{\mathrm{e}}$ が増加するが, 同時に, 両者の差 $\left(q_{\mathrm{t}}-q_{\mathrm{e}}\right)$ も増加 している。この差

$$
q_{\mathrm{t}}-q_{\mathrm{e}}=\left(1-\eta_{\mathrm{s}}\right) \frac{Q_{\mathrm{c}}+Q_{f}}{A_{\mathrm{b}}}\left(\mathrm{W} / \mathrm{m}^{2}\right)
$$


に相当する熱量が, フリーボードへ移行し，フリーボー ド温度の上昇を招くことになる。

なお，本実験では前述の通り，操作条件を通常運転時 より拡張して行ったが, 熱分解域 $(m<1.0)$ や高空気質 量速度時の排ガス及び焼却残渣の性状については他 (Kasakura and Imoto, 1991. : Kasakura et al., 1991) に報告した様に，高い空気質量速度では一酸化炭素の発 生量が増加する等の現象はあるが，いずれにしても焼却 プロセス上から対応可能であり, 問題は無い.

\section{結言}

流動焼却パイロットプラントを用いて焼却実験を行い 下水污泥流動床焼却炉の性能特性のいくつかを明らかに することができた。

（1）流動層砂層内燃焼率はケーキ負荷の増加と共に低 下する. また, 砂層内燃焼率は, 補助燃料負荷の増加と 共に低下した，更に，空気質量速度の増加と共に低下し た。

（2）空気比 $m$ と砂層内燃焼率 $\eta_{\mathrm{s}}$ の関係は熱分解域で はほぼ一次比例した。 また, 実験条件の範囲 $(818 \sim 1,171$ K）では燃焼率と砂層温度の間には明確な相関は見出せ なかった。

（3）空気質量速度の高い領域でも高いケーキ負荷での 安定燃焼の維持が可能であった。但し，高いケーキ負荷 では安定燃焼の維持のために筀気比を高める必要性が認 められた。

（4）空気質量速度を増加すると有効炉床熱負荷の上限 も増加した。 また，同時にフリーボードへ移行する熱量 も増加した。

[謝 辞] 本研究は, 名古屋大学工学部分子化学工学科架谷昌 信教授の指導と助言を受けて行われたものである.ここに記して 謝意を表します。

\section{Nomenclature}

$A_{\mathrm{b}}=$ bed cross sectional area

$\left[\mathrm{m}^{2}\right]$

$A_{\mathrm{s}}=$ contact area of bed material

$C_{\text {pash }}=$ specific heat of ash

$C_{\text {pcomb }}=$ specific heat of combustible gas

$C_{\text {pdry }}=$ specific heat of dry exhaust gas

$C_{\mathrm{pH}_{20}}=$ specific heat of vapor

$d_{\mathrm{p}}=$ particle diameter of bed material

$F_{\text {al }}=$ air feed rate $=F_{\text {aidry }}+F_{\mathrm{alH}_{2} \mathrm{O}}$

$F_{\text {aidry }}=$ dry air feed rate

$F_{\mathrm{aiH}_{2} \mathrm{O}}=$ vapor feed rate of air

$F_{\mathrm{c}}=$ cake feed rate

$[\mathrm{J} / \mathrm{kg} \cdot \mathrm{K}]$

$[\mathrm{m}]$

$[\mathrm{kg} / \mathrm{h}]$
$F_{\mathrm{f}}=$ fed fuel rate

$[\mathrm{kg} / \mathrm{h}]$

$F_{\text {gdry }}=$ mass flow rate of dry exhaust gas

$[\mathrm{kg} / \mathrm{h}]$

$F_{\mathrm{gH}_{2} \mathrm{O}}=$ mass flow rate of vapor in exhaust gas $[\mathrm{kg} / \mathrm{h}]$

$F_{\mathrm{w}}=$ water feed rate in fed cake

$[\mathrm{kg} / \mathrm{h}]$

$f \quad=$ fed fuel ratio $=Q_{\mathrm{f}} /\left(Q_{\mathrm{c}}+Q_{\mathrm{f}}\right)$

$[-]$

$H_{\text {ch }}=$ high calorific value of cake

$[\mathrm{MJ} / \mathrm{kg}]$

$H_{\mathrm{c} l}=$ low calorific value of cake

$[\mathrm{MJ} / \mathrm{kg}]$

$H_{\mathrm{fh}}=$ high calorific value of fuel

$[\mathrm{MJ} / \mathrm{kg}]$

$h_{\mathrm{c}}=$ hydrogen content based of cake solid $\quad[-]$

$h_{\mathrm{f}}=$ hydrogen content based of fuel

$[-]$

$h_{\mathrm{s}}=$ heat transfer coefficient

$\left[\mathrm{W} / \mathrm{m}^{2} \cdot \mathrm{K}\right]$

$k_{\mathrm{c}}=$ theoretical combustion air rate of cake

$[\mathrm{kg} / \mathrm{kg}]$

$k_{\mathrm{f}}=$ theoretical combustion air rate of fuel $[\mathrm{kg} / \mathrm{kg}]$

$L \quad=$ latent heat

$[\mathrm{J} / \mathrm{kg}]$

$m=$ air ratio $=F_{\text {al }} /\left(F_{\mathrm{c}} \cdot S \cdot k_{\mathrm{c}}+F_{\mathrm{f}} \cdot k_{\mathrm{f}}\right)$

$Q_{\mathrm{ai}}=$ quantity of sensible heat caused by fluidized air

[W]

$Q_{\text {ash }}=$ quantity of sensible heat caused by ash

[W]

$Q_{\mathrm{c}}=$ quantity of heat caused by cake combustion

[W]

$Q_{\text {comb }}=$ quantity of sensible heat caused by combustible gas

[W]

$Q_{\mathrm{f}}=$ quantity of heat caused by fuel combustion

$Q_{9}=$ quantity of sensible heat caused by exhaust gas

$Q_{\mathrm{H}_{2} \mathrm{O}}=$ quantity of latent heat

[W]

$Q_{\text {Los }}=$ quantity of heat loss

[W]

$q_{\mathrm{e}}=$ effective heat load in sand bed

[W]

$q_{\mathrm{t}}=$ total heat load in sand bed

$\left[\mathrm{W} / \mathrm{m}^{2}\right]$

$r_{\mathrm{c}}=$ cake load

$\left[\mathrm{W} / \mathrm{m}^{2}\right]$

$r_{\mathrm{f}}=$ fuel load

$\left[\mathrm{kg} \cdot / \mathrm{m}^{2} \cdot \mathrm{h}\right]$

$r_{\mathrm{T}}=$ fuel load

$r_{\mathrm{s}}=$ solid load

$r_{\mathrm{w}}=$ water load

$\left[\mathrm{kg} \cdot / \mathrm{m}^{2} \cdot \mathrm{h}\right]$

$\left[\mathrm{kg} \cdot / \mathrm{m}^{2} \cdot \mathrm{h}\right]$

$\left[\mathrm{kg} \cdot / \mathrm{m}^{2} \cdot \mathrm{h}\right]$

$[-]$

$\left[\mathrm{m}^{2}\right] \quad T_{\mathrm{f}}=$ freeboard temperature [K]

$[\mathrm{J} / \mathrm{kg} \cdot \mathrm{K}] \quad T_{\text {out }}=$ exhaust gas temperature $\quad[\mathrm{K}]$

$[\mathrm{J} / \mathrm{kg} \cdot \mathrm{K}] \quad T_{\mathrm{s}}=$ bed temperature

$[\mathrm{K}]$

$u_{0}=$ superficial air velocity

$[\mathrm{m} / \mathrm{sec}]$

$[\mathrm{J} / \mathrm{kg} \cdot \mathrm{K}] \quad V=$ volatile matter content of cake solid

$[-]$

$W=$ water content of cake $=100(1-\mathrm{S})$

$[\%]$

$[\mathrm{kg} / \mathrm{h}] \quad \eta_{\mathrm{c}} \quad=$ combustion efficiency of cake $\quad[-]$

$[\mathrm{kg} / \mathrm{h}] \quad \eta_{\mathrm{f}} \quad=$ combustion efficiency of fuel $\quad[-]$

$[\mathrm{kg} / \mathrm{h}] \quad \eta_{\mathrm{s}}=$ combustion efficiency at fluidized bed $\quad[-]$ 
$\rho_{\mathrm{a}} \quad=$ air density

\section{Literature cited}

Ibuki, M.: "Incineration of Dried Sewage Sludge using a Fluidized Bed Furnace”, NGK Kankyosochi News, 9, 66 77 (1983)

Kasakura, T. and Y. Imoto, : "Study on Sewage Sludge Incineration using a Fluidized Bed Furnace", Gesuido Kyokai Ronbunshu, 28, 72 82 (1991)

Kasakura, T., Y. Imoto, and M. Hanano, : “Study on Sewage
Sludge Pyrolysis using a Fluidized Bed Furnace", Kankyo Gijutsu, 20, 367 -378 (1991)

Muchi, I., S. Mori, and M. Horio,: "Ryudoso no Hanno Kogaku”, Baifukan (1984)

Ohi, K. and T. Takebayashi, : "Consideration about Fludized Bed Incineration of Sewage Sludge", Nenryo oyobi Nensho, 46, 53 61 (1979)

Paul B. Liao.: "Fluidezed-Bed Sludge Incinerator Design", Journal of W. P. C. F, 46, 1895 1913 (1974)

\title{
Performance of a Fluidized Bed Furnace for Sewage Sludge Incineration
}

\author{
Yoshinori Imoto and Tadao Kasakura*
}

NGK Insulators, Ltd.

\begin{abstract}
Key Words: Fluidized bed incinerator, Environment, Sewage sludge, Air mass velocity
\end{abstract}

A fluidized bed furnace with a $0.7 \mathrm{~m}$ square sand bed was operated with air mass velocity of 0.19 to $0.6 \mathrm{~kg} / \mathrm{m}^{2} \cdot \mathrm{s}$, compared to ordinary rates of 0.20 to $0.25 \mathrm{~kg} / \mathrm{m}^{2} \cdot \mathrm{s}$. The air ratio was adjusted over a wide range of 0.62 to 1.50 , compared to ordinary rates of 1.3 to 1.5. From the results of these experiments, the combustion efficiency at sand bed decreased as cake load, fuel load and air mass velocity increased. The combustion efficiency is proportional to the air ratio, therefore the combustion efficiency decreased as the air ratio decreased. A definite correlation of combustion efficiency and sand bed temperature was not obeserved in the range of $873-1,171 \mathrm{~K}$ under the self combustion condition. At a high air mass velocity, the operation of the high cake load can be accomplished with a high air ratio. And at high cake load the freeboard combustion was superior to sand bed combustion.

* Toyohashi University of Technology. 